\title{
Monika Talarczyk
}

Lodz Film School

\section{The Other Sex of Polish Cinema. The Contribution of Female Filmmakers to Feature Film Production in the People's Republic of Poland}

\section{Introduction}

The emancipation of Polish women in socialism was one of the leading propaganda postulates, the subject of social and cultural policy. This emancipatory tradition of a bygone era makes one wonder what production culture patterns determined the place of women in the state film industry and what the contribution of women in terms of their numbers and character of their work was. It is impossible to make a diagnosis of their current condition in the film industry without a reference point, i.e. the film industry of People's Poland. The need to determine such a reference point results, for example, from the fact that women filmmakers now occupy a leading position in film art and among filmmakers. Associated in the social movement the Film Women, they are trying to carry out actions to modernize film culture for the benefit of gender balance but they are hardly able to determine what tradition in the history of the Polish film industry is behind these activities. In other words, is the cinema of the Polish People's Republic a negative or positive point of reference. Especially that nowadays, they are accused of returning to a bygone era, in which the chances of underrepresented social groups such as workers or peasants were equalized and the professional advancement of women was encouraged. 
Of course, Polish and English studies of the subject have already been created but they all focused on the work of female directors or screen representations of women (Quart, 1988; Iordanova, 2003; Falkowska, 2003). The pioneering book by Ewa Mazierska and Elżbieta Ostrowska, Women in Polish Cinema (2006) was devoted to four authors: Wanda Jakubowska, Barbara Sass, Agnieszka Holland and Dorota Kędzierzawska, as well as the images of the Polish Mother in Polish film and the heroines of the Polish School of Film. In the book, Biaty mazur. Kino kobiet w polskiej kinematografii (2013b) I expanded this selection of authors with other feature filmmakers, professionals who have been successful to a smaller or greater extent: Maria Kaniewska, Anna Sokołowska, Jadwiga Kędzierzawska, Ewa Petelska, Agnieszka Osiecka, Ewa Kruk, Hanka Włodarczyk, Magdalena Łazarkiewicz and women screenwriters who were also the authors. Nevertheless, it was the directors who mainly remained in the orbit of research interest and among them mostly those who managed to create several or even a dozen or so films unlike Ewa Kruk or Agnieszka Osiecka. Focusing on the domain of directing, one can get the impression that women's cinema was a niche critical concept that can be only applied to the analysis and interpretation of films by a few women directors. Its analytical use increases if we shift our attention to the culture of work in film production. Then the focus is on the professional biographies of female filmmakers as well as national patterns of film culture and work in the film industry. The field of research is significantly expanded if we take into account the input of representatives of other professions.

Studies on the culture of production have redirected our attention from work on the set to behind the scenes aspects of production. Under the influence of author's policy and other prevailing, non-productive concepts of cinema (film aesthetics, national cinemas, film semiotics) in film studies, we have long forgotten that a film work is the result of teamwork and if we want to have a full picture of the phenomenon of film production and work culture, attention should also be paid to other creative employees, their assistants and technical employees. Already a critic author's policy, Pauline Kael, from the very beginning of the career of the concept of author's film, contested the view that a film is an expression of the vision of one person - the author, pointing out that in other fields of art, the contribution of all those involved in the production process of the work has been taken into account when assessing its values (Kael, 1963, p. 15). Undoubtedly, in addition to the principles of working on a film set, film production is also organized by various metaphors. According to a classic of production studies, John Caldwell, a true understanding of the culture of production means recognizing its Janus face: one explains it in common sense concepts, the other, puts it in allegorical generalizations (Caldwell, 2008, p. 26). In the Polish People's Cin- 
ema such an allegory constitutes the character of Agnieszka (Krystyna Janda) in Andrzej Wajda's Cztowiek z marmuru (The Man of Marble, 1976) a film school student who seeks the truth about a labour leader from the Stalinist period, is assisted by two filmmakers, an operator and a sound engineer, condemned to an almost lonely fight and eventually deprived even of the camera. The character of Agnieszka was an allegory of the Solidarity Cinema, produced by the state but also defending the working class and the filmmaker's right to seek the truth about the history of People's Poland. Like an allegory of revolution, it led a worker to the barricades of television. In the end, the most helpful person for Agnieszka was the female editor (M. Wójcik) from the archives of the Feature and Documentary Film Studio in Warsaw who found rejected materials about the worker. She ironically commented on her position with the words: "I'm not here to think but to splice". She must have heard this many times, but not from Wajda, who with this key role for Agnieszka's success paid a tribute to his longtime collaborator, an excellent editor, Halina Prugar. This character seems much closer to reality than the reckless fantasy of a young director. Stories about the genius and determination of an individual should be confronted with the documentation revealing the contribution of all the crew and track the careers of not only women as directors but also the creators in other film professions.

\section{The Method}

Convinced of the gender perspective potential, I would like to complement this Janus face of the production culture with a female perspective. Women's studies found in the production culture an unexpected ally, thanks to shedding light on the film's production contributors usually hidden in the crew: production managers, editors, script and continuity, just to mention a few most feminized film professions. Interestingly, the traces of the sexual division of work are extremely persistent and clear on both sides: creative and technical, and sometimes even defined in gender in the industry names of film professions such as e.g., script girl or best boy. It is time to check which film professions in the crews of feature films in the state film industry of the People's Republic of Poland were feminized, which were balanced in terms of sex, and which were practically unavailable for women. Who were the pioneers and women of success in individual film professions? How did the recruitment policy for the Film School influence their later professional activity? How did groundbreaking events in political or social history correlate with the increase or decrease in the number of feature films featuring women in the crew. I assume that the results of quantitative research in the field of Polish feature film of this bygone era would allow for the conducting of comparative studies with neighbouring film industries of the

\section{6}


Eastern Bloc where the programme of social policy, including women's professional activation, was generally the same.

The inspiration to undertake research in the history of Polish cinema were the articles of Beata Hock, who conducted quantitative and qualitative research in the history of Hungarian film, i.e. the inclusion of women in the production of feature films and the representation of women on screen (Hock, 2010, 2012). She updated the results to 2005 which allowed a comparison of state cinema with the cinema of the transformation period to be made. She included feature films in them calculating the participation in key positions of women in the crew: director, script writer, storyline editor, editor, costume designer, production manager, including a mixed-gender team in the position (when applicable). In the second study, she expanded the range of film professions with the following: cinematographer, choreographer, assistant director, lyrics, idea, music, special effects, set designer, sound, producer. She ordered the results into 5-year data blocks. The task I set for myself is limited to quantitative research and covers the period 1945-1989; it includes: director, assistant director, scriptwriter, cinematographer, music, set designer, costume designer, editor, production manager. The time span limit of the studies is not due to the lack of data (I have brought this research up to the present day and supplemented it every year), but from the belief in the need for comparative studies of the Eastern Bloc in the era of state film industries, whose only next stage would be to examine the dynamics of transformation in its impact on the film industry. I share Hock's view that, from the point of view of feminism, the most favourable is a balanced gender distribution in each of the creative, assistant and technical professions, so that women have access to the widest possible group of tasks (Hock, 2010, p. 11). I could add that overrepresentation of any of the sexes serves neither the dominant nor the dominated one as it creates gender specific rules of work on the set which make room for the minority group to be used and creates a gendercentric world in which the other sex feels strange and can be abused on the set. Let us follow the results of quantitative research in subsequent periods and try to embed them in the context of changes in film culture.

\section{5-49}

After the war, the creation of state-owned film industry of the People's Poland was entrusted to filmmaker-soldiers from the Film Unit of the Polish Army which was formed alongside the Red Army. Most of them were male and female members of the pre-war Association of Artistic Film Lovers START. Some of them, like Olga Mińska-Ford, accompanied their partners in arms, others, such 


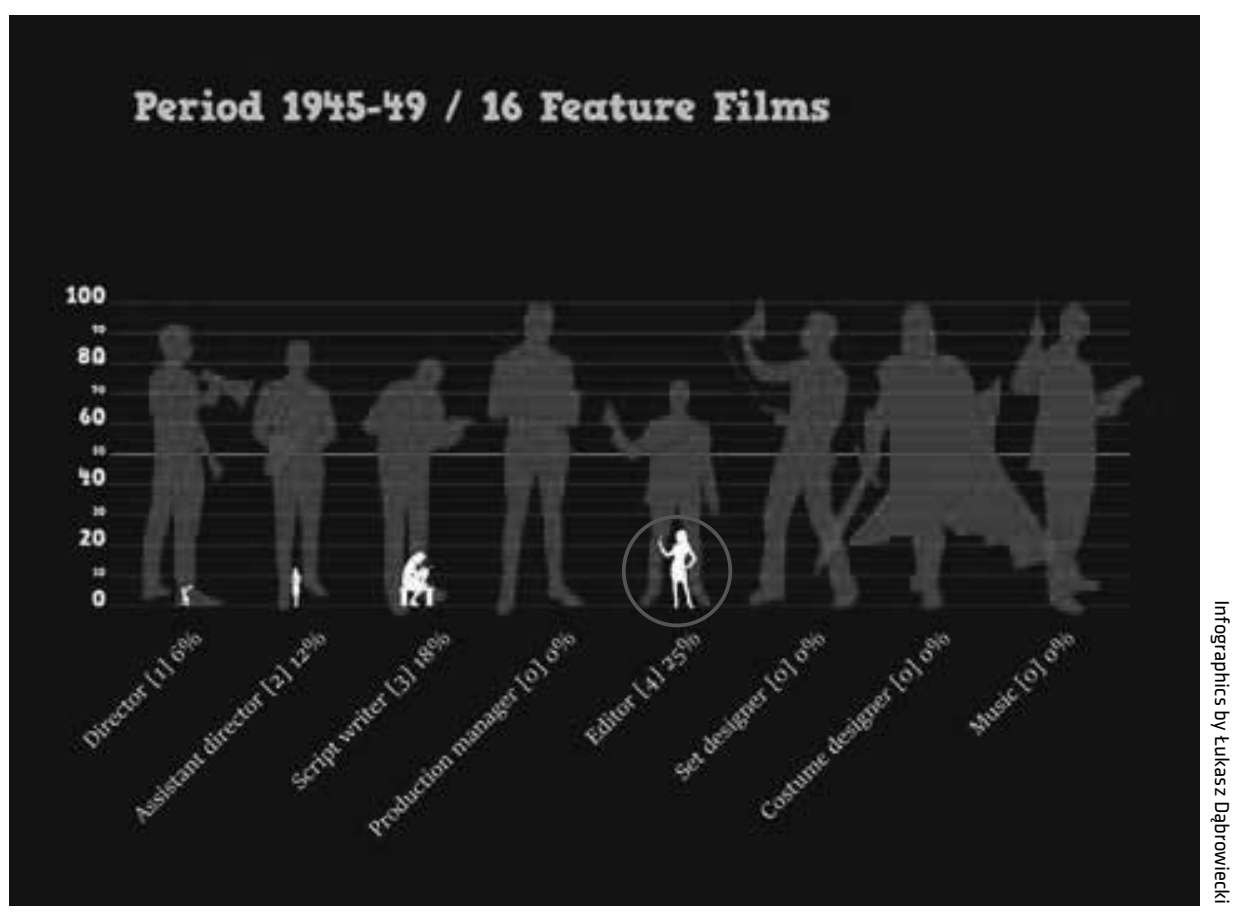

as a Russian, Ludmila Niekras, became involved with the Polish operator during the war. Naturally, a START member and a survivor from the Auschwitz-Birkenau camp, Wanda Jakubowska, also joined the group of soldiers-filmmakers and their comrades-in-arms. Since START before the war formed the largest group of kinophiles (280 people according to the Toeplitz's list from 1933) and one-third of the members were women, it can be assumed that it was a progressive group and conducive to women's careers in film. Nevertheless, Jakubowska, who was the only one to come up with her own film project, met with a lack of confidence from her colleagues regarding her directing skills (Talarczyk-Gubała, 2015). Nevertheless, determined, she led the production of the film Ostatni etap (The Last Stage, 1948) in which the participation of women behind and in front of the camera is exceptional and places this film very highly in the Bechdel test ranking. In a group of 16 feature films produced in 1945-49, even one film made by a woman raised statistics, in addition it was co-scripted by Gerda Schneider and featuring female collective heroine. Jakubowska's film was a milestone in women's cinema in the Eastern Bloc, in addition to international publicity. Its uniqueness becomes even more apparent if we consider that, e.g. in Hungarian cinema, the first feature films directed by a woman were made only in the 1960s (Éva Zsurzs television films and Marta Meszaros cinema films), and earlier on, 
even a female director's assistant was rare, maximum 6\% (Hock, 2012, p. 97). The situation in the film industry in the People's Poland was different. Women assistants, co-workers and second directors assisted male directors in nearly half of the feature films made throughout the entire era. The highest result in the post-war years, i.e. $25 \%$, refers to the participation of women in film editing. What is more, as many as 3 of the first 4 post-war feature films were edited by the same editor: Róża Pstrokońska. Like other pioneers, she gained film education and experience before the war. She started working in the film industry in 1927 as a restorer at the Gaumont agency in Warsaw. She was trained in editing by Zbigniew Gniazdowski, a pre-war cinematographer. She worked in the profession till the 1970s.

\section{0-55}

During the period of socialist realism, the political agenda dedicated to women was the most intense, the number of working women increased and the visibility of women in culture increased. The gender of the director and the heroines were discussed in "Film" beweekly, the female director and a woman engaged in public issues on the screen was a symbol of the progress of socialist film in-

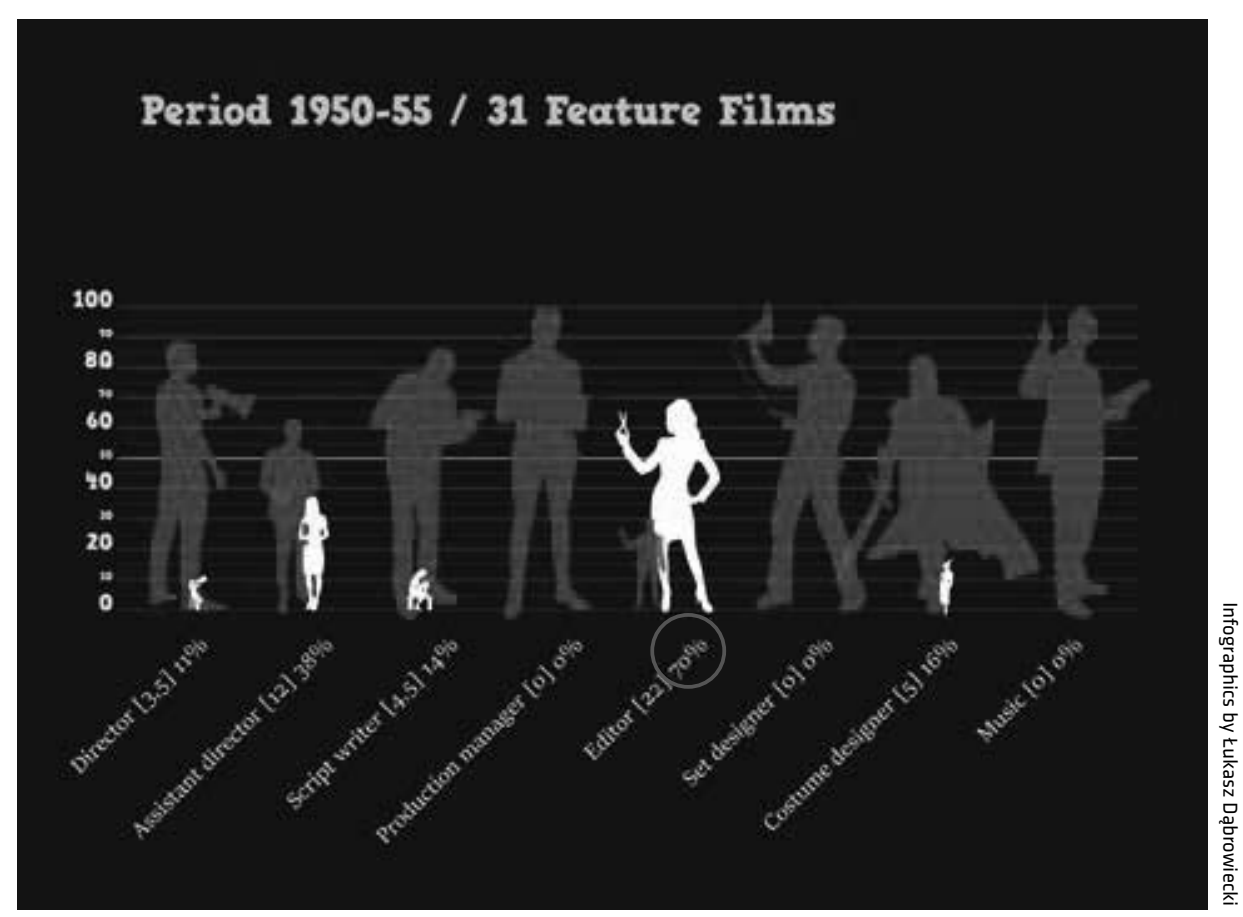


dustries and a subject of competition in this field. In those years, the number of women studying directing at the Film School in Łódź was the highest, reaching $25 \%$, and in 1953 parity was achieved without any prior assumption. Nevertheless, during their studies, women were discouraged from becoming a director, including by the legendary lecturer Prof. Antoni Bohdziewicz. As a result, some of them gave up, others took up documentary filmmaking, and two others entered the Polish cinema, but not without obstacles. Lidia Zonn, discouraged from directing, took up editing and became a master in the field of documentary film. Zofia Dwornik, after political affair connected with her father's death in Katyń, was transferred to editing studies (Talarczyk, 2013b, p.49). In turn, the best known, Barbara Sass, on the advice of teachers, including Maria Kaniewska, as the so-called attractive blonde changed her studies to acting only to return to directing a year later (Talarczyk, 2013a, p.295-296). As we know, eventually, she became a classic of women's cinema in Poland. None the less, her path to the profession was long and she worked for over a dozen years as a second director or assistant director. Also characteristic of this stage were film marriages which jointly developed careers. Barbara Sass married the cinematographer, Wiesław Zdort, Maria Kaniewska married cinematographer, Adolf Forbert and Ludmila Niekras married Ludwik Perski. As Sass explains, marriage to a filmmaker did not automatically mean everything was easy. On the contrary, it added to rumours about them being supported by their husband's in their film careers, and the employer - the State Enterprise "Film Production Units" - recognized that since the industry already pays for one bread winner in the family, the other does not require employment. Thus, many women functioned in the film industry as the wives of male industry insiders.

On the other hand, female directors provided official and private support to one another which was significant for this period. Jakubowska made Kaniewska her assistant at the Film School in Łódź and supported her direction debut. Kaniewska, in turn, chose Ewa Petelska, one of the first talented graduates of directing. In a short time, Petelska began her prestigious career alongside her husband, Czesław, and never directed individually, apart from her student films. In the field of editing, the amount of women's involvement in the feature film editing increased to $70 \%$. It is assumed that the first generation of editors was educated by Ludmila Niekras and Wacław Kaźmierczak. The feminization of editing was a global phenomenon from the beginning, both in Hollywood and in the Soviet Union (Talarczyk, 2018). However, this did not apply to all film industries as can be concluded from the Hock's study. In the Hungarian cinema, 
the number of films edited by women accounted for a dozen or so percent up to the mid-sixties, and only in the second half of the seventies up to $75 \%$ of feature films (Hock, 2012, pp. 90-95).

\section{6-60}

During the political thaw in Poland, women's emancipation was halted and even reversed. Female filmmakers active in socialist realism became the object of resentment and mockery. The most severely evaluated were those of socialist realist films which had been directed by women: Soldier of Victory (Żołnierz zwycięstwa, 1953) by Wanda Jakubowska and Near Warsaw (Niedaleko Warszawy, 1954) by Maria Kaniewska. Despite this, the percentage of women in feature films directing was the highest in the history of People's Poland Cinema $-14 \%$. They owed it to feature films for children and young people, the type of the cinema in which they withdrew from the mainstream, with the approval of film critics and probably also their male colleagues. They did not lower the level, on the contrary, they created a classic cinema for children: Król Maciuś I (King Matt I, 1957, dir. Wanda Jakubowska) and Awantura o Basię (The Basia's Affair, 1959, dir. Maria Kaniewska). Critics were relieved that women had finally taken

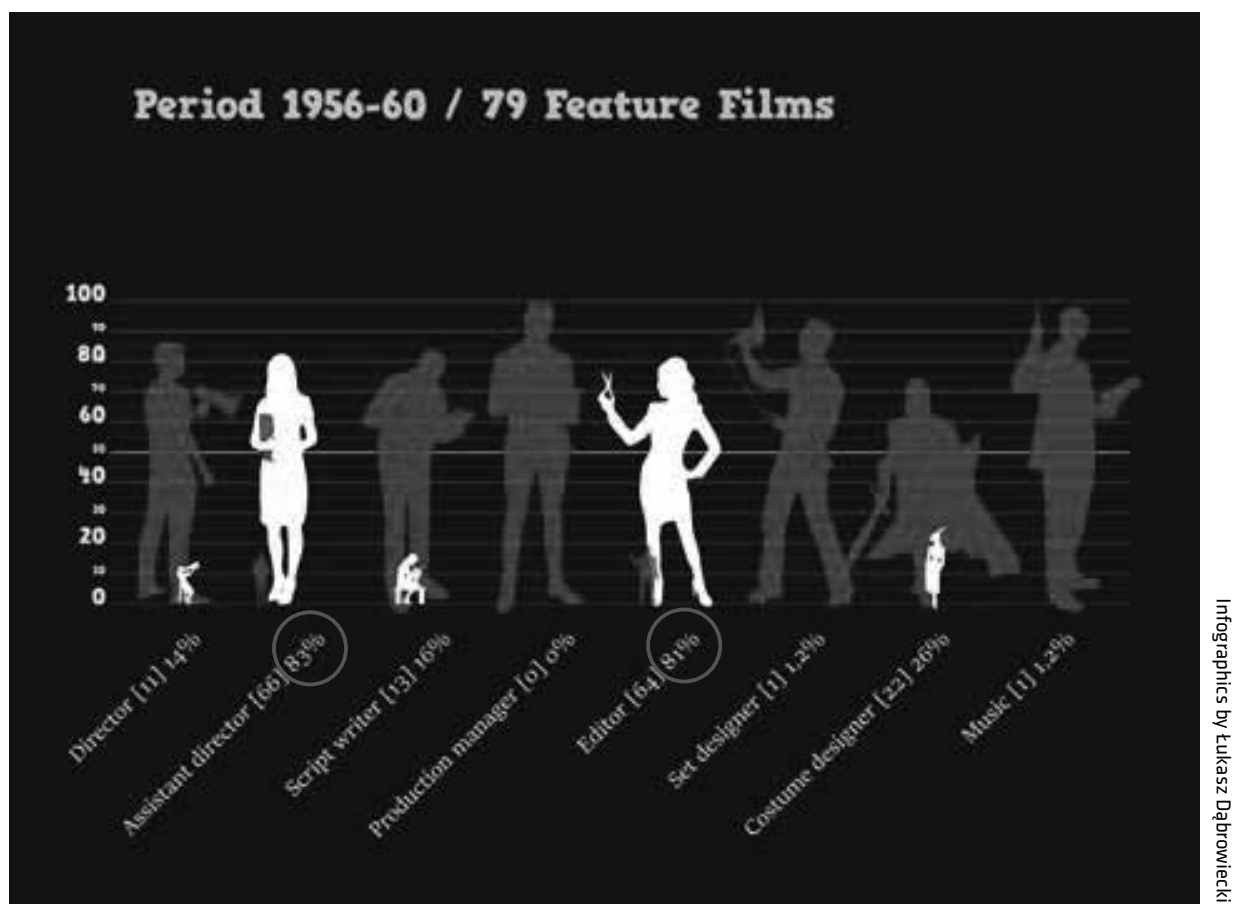


up their natural destiny, a cinema for the young viewer. Among the director's assistants, women appeared in most of the productions $-60 \%$, as they graduated from the Film School in Łódź in large numbers. However, this result requires even more precise calculations, namely the number of women in the group supporting the director in relation to men. However, during the thaw, the recruitment policy changed, 1 female student at most was admitted to the group of 7-8 male directing students in a year. Costume design was not yet the domain of women. Costume designers were recruited from graduates of the Academy of Fine Arts, and these were dominated by men. Interestingly, in the Hungarian film industry female costume designers worked in this role from the beginning, perhaps because they combined it with the position of production manager. By the 1960s, Hungarian women were in charge of costumes in over $80 \%$ of feature films (Hock, 2012, p. 90).

\section{1-65}

During the so-called small stabilization of the first half of the sixties, which we cannot read from the numbers, the position of women in Polish cinema for children and young people stabilized, few - like Jakubowska - persisted in mak-

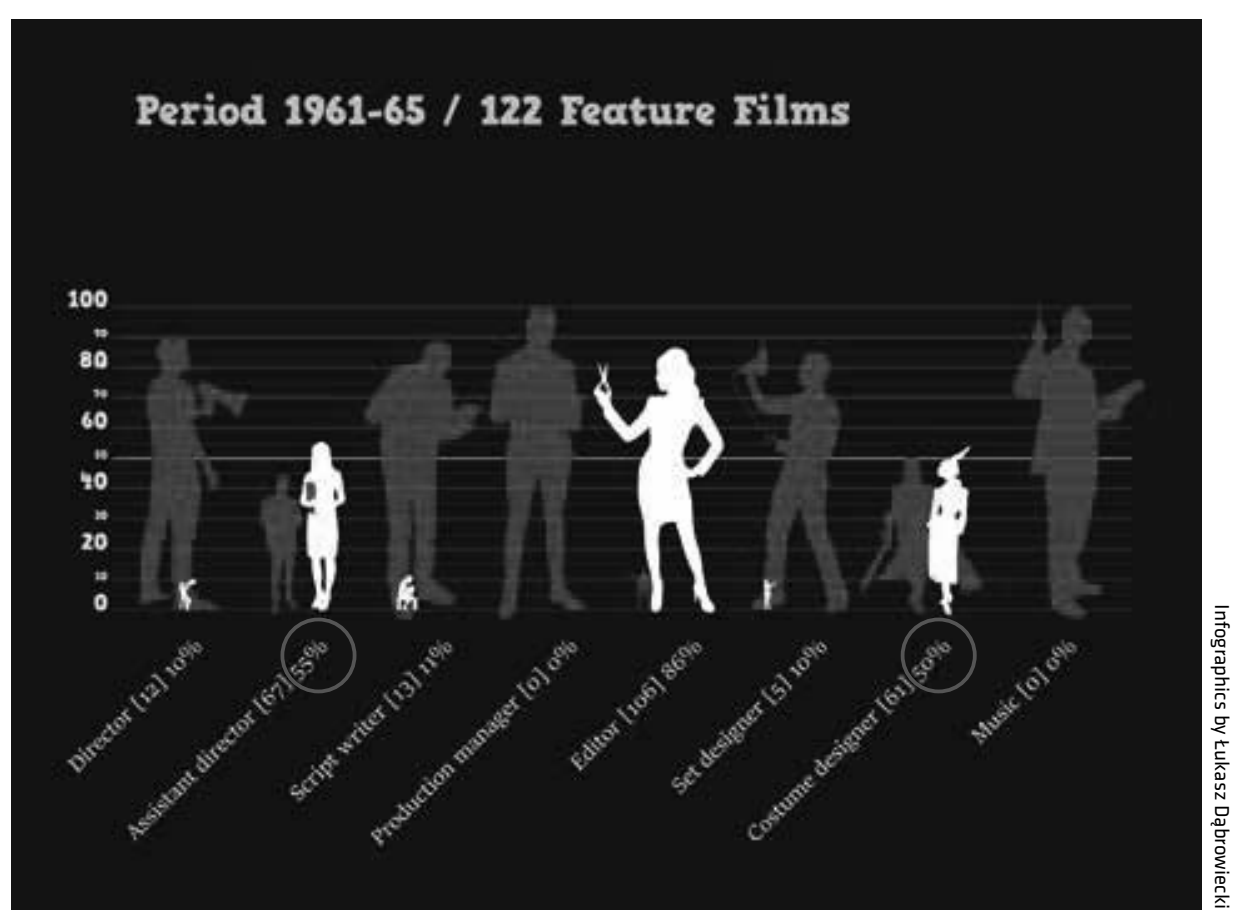


ing feature films for adult audiences. Among the directors active at that time, it is worth noting Halina Bielińska, who successfully found herself in both currents: the main one - in the psychological drama for the adult viewer, with the participation of a star e.g., Zbyszek Cybulski in Sam pośród miasta (Alone in the City, 1965), and a side one - costume film for the young viewer - Godzina pasowej róży (Hour of the Crimson Rose, 1963) based on the novel by her sister, Maria Kruger. In addition, she was a pioneer of animation in post-war Polish film, winning the Golden Palm Award in Cannes for the animation Zmiana warty (The Change of the Guard, 1958), which she created with Włodzimierz Haupe. She also worked as a set designer for animated films. However, set design for feature films had never become the domain of women, in the entire period studied they designed in this respect only $11 \%$ of feature films.

\section{$1966-70$}

In the second half of the sixties, two world-wide events affected the condition of Polish film and the film circles to varying degrees: the Six-Day War in the Middle East and, in all proportions, the second wave of feminism. In March 1968 , as a result of the persecution by the People's Poland authorities of the in-

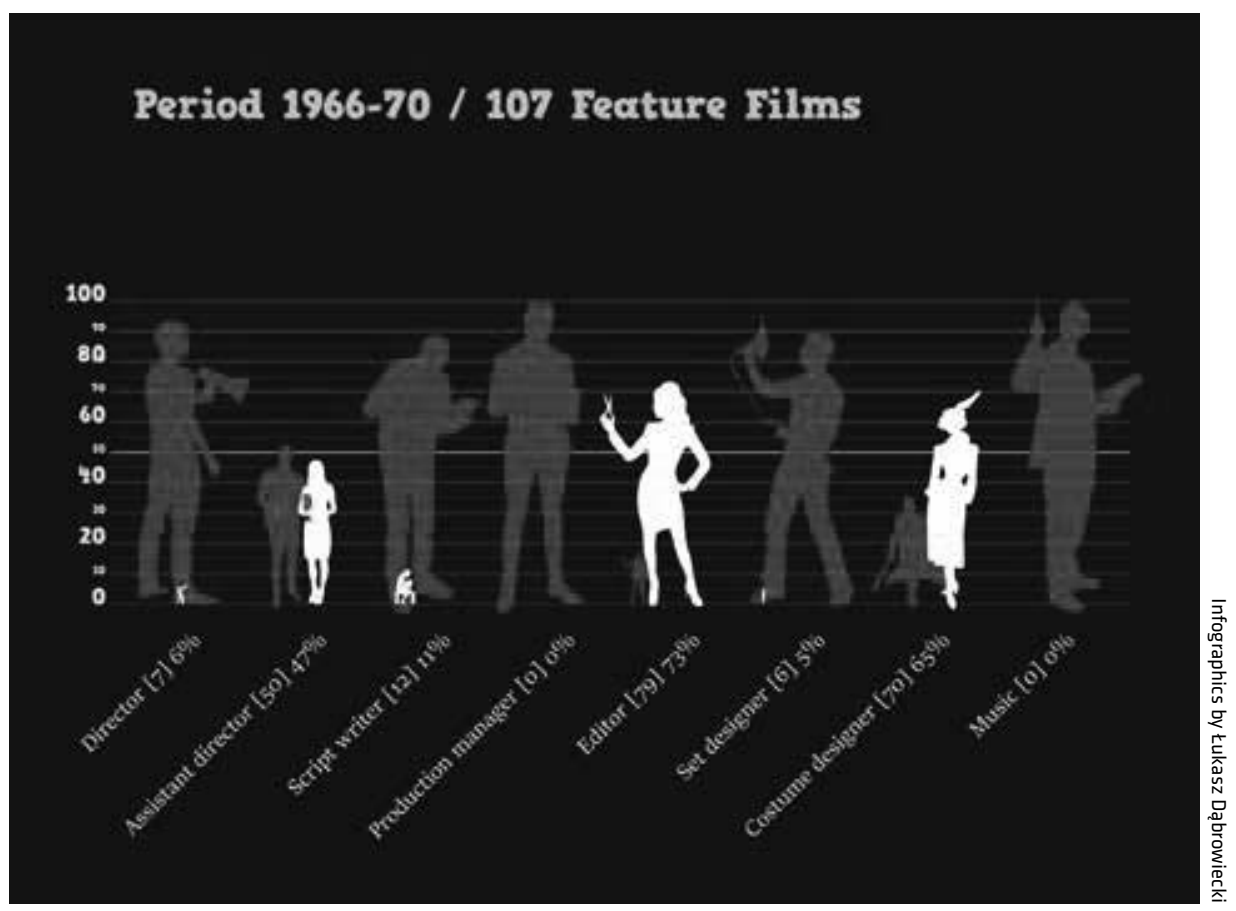


telligentsia and creators of Jewish origin, many of these lost their jobs and were forced to leave the country. This group also included former START members, founders of post-war film industry, mostly of Jewish origin. It is difficult to estimate the impact of March'68 on female filmmakers, the awareness of the Jewish origin of some of them was not common nor did they have the power enjoyed by female editors or politicians from the Stalinist period. As a result, such directors as Ewa Petelska or Anna Sokołowska, both of Jewish descent, remained with their partners in the country. In turn, the second wave of feminism collided in Poland with the political crisis caused by March 1968. Press articles show that gender in various film professions was discussed in the film circles which pondered whether male and female films exist - without consensus (Iskierko, 1969, p.10). But the life tragedies caused by the anti-Semitic campaign have pushed most of the issues to the background. In addition, emancipation postulates could have been associated with Stalinism, the so-called "period of errors and distortions", and not progress in this field.

\section{1-75}

In the first half of the seventies, female production managers began to organize feature film production. Studies in this specialization had been conducted at the Film School in Łódź since the 1950s, however, women started to be entrusted with managerial duties later. On the one hand, this was supported by the development of television, and on the other, the loss suffered by the industry as a result of the forced emigration of production managers of the older generation. The most recognizable and successful was Barbara Pec-Ślesicka as the production manager of Film Unit X under the artistic direction of Andrzej Wajda, despite the fact that the most famous films produced by $\mathrm{X}$ were made in the second half of the seventies, during the economic and political crisis. Basic articles were barely obtainable. However, in the first half of the decade, during the so-called "propaganda of success" period, women managed the production of costume adaptations of Polish literature which were demanding in terms of materials and staff. Such films were produced by Urszula Orczykowska, Helena Nowicka and others. The number of films in which women were responsible for costumes and set design also increased. Among the artists worth mentioning who were part of this group were e.g., a costume designer, Anna Biedrzycka who years later was nominated for an Oscar for the costumes for the film Schindler's List and Ewa Braun, a costume and interior designer, with time also an art director and Oscar winner for art direction for Schindler's List. Quantitative research also indicates the incidental work of women as the authors of film score. These occurrences were absolute exceptions: two compositions by Wanda Warska for

\section{4}




\section{Period 1971-75 / 107 Feature Films}

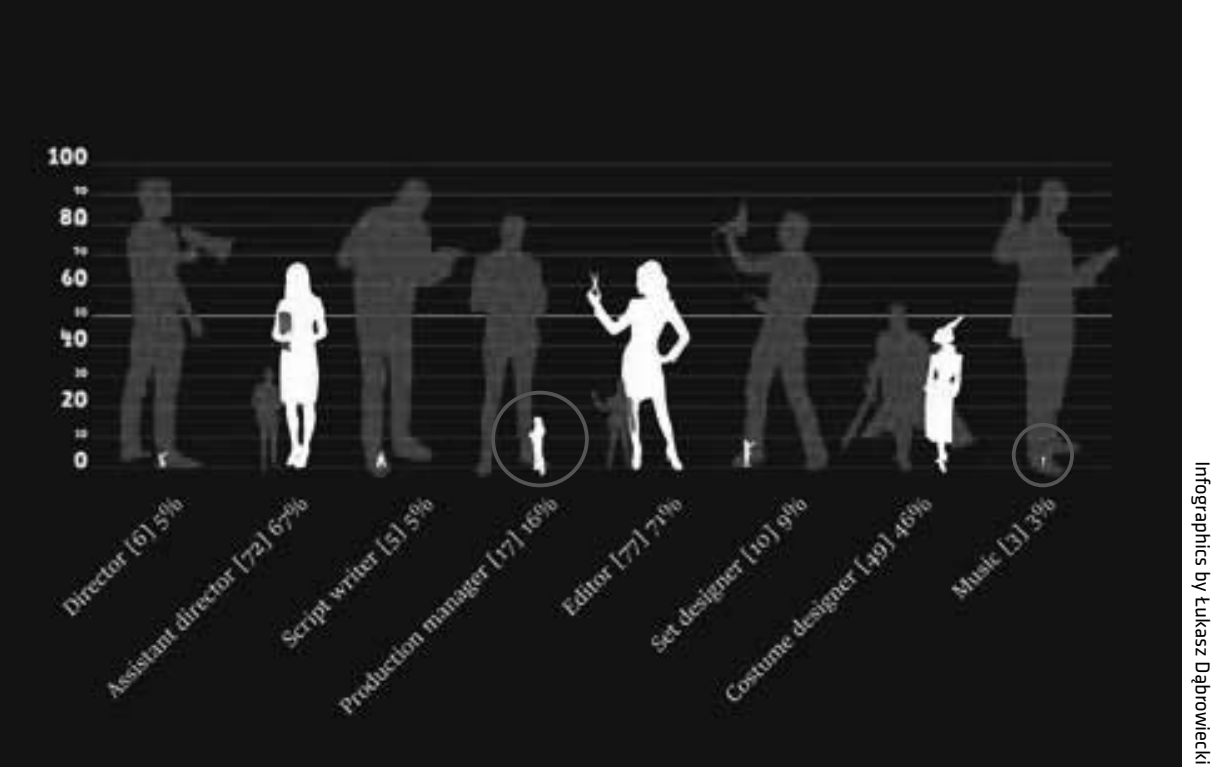

films for young people with a girl as the main character, Jezioro osobliwości (The Lake of Peculiarities, 1972, dir. Jan Batory) and Karino (1974,1976, dir. Jan Batory) were somehow a side-effect of her position in jazz music at the time and the cult vocal in Jerzy Kawalerowicz's Train. In turn, Alina Piechowska, the author of music for Roman Załuski's melodramas: Anatomia mitości (Anatomy of Love, 1972) and Kardiogram (Cardiogram, 1971), was a gender indicator of the genre of a film about unhappy love. She was a pianist, conductor, poet and teacher, who immigrated to Paris. The same situation was present in the Hungarian film industry: music from $1 \%$ in the period $71-75$ to a maximum of $4.5 \%$ in the $1980 \mathrm{~s}$ (Hock, 2012, pp. 92-93).

\section{6-80}

In the second half of the seventies, the percentage of films directed by women grew from $5 \%$ to $7 \%$. In terms of numbers, the change was small, but substantial in terms of quality. We can say that it was a generational change - veteran assistants like Barbara Sass and the younger generation representatives - like Agnieszka Holland - both from the Film Unit X stepped in. Holland became Wajda's main collaborator and the second authority in the Film Unit X, Sass discouraged 


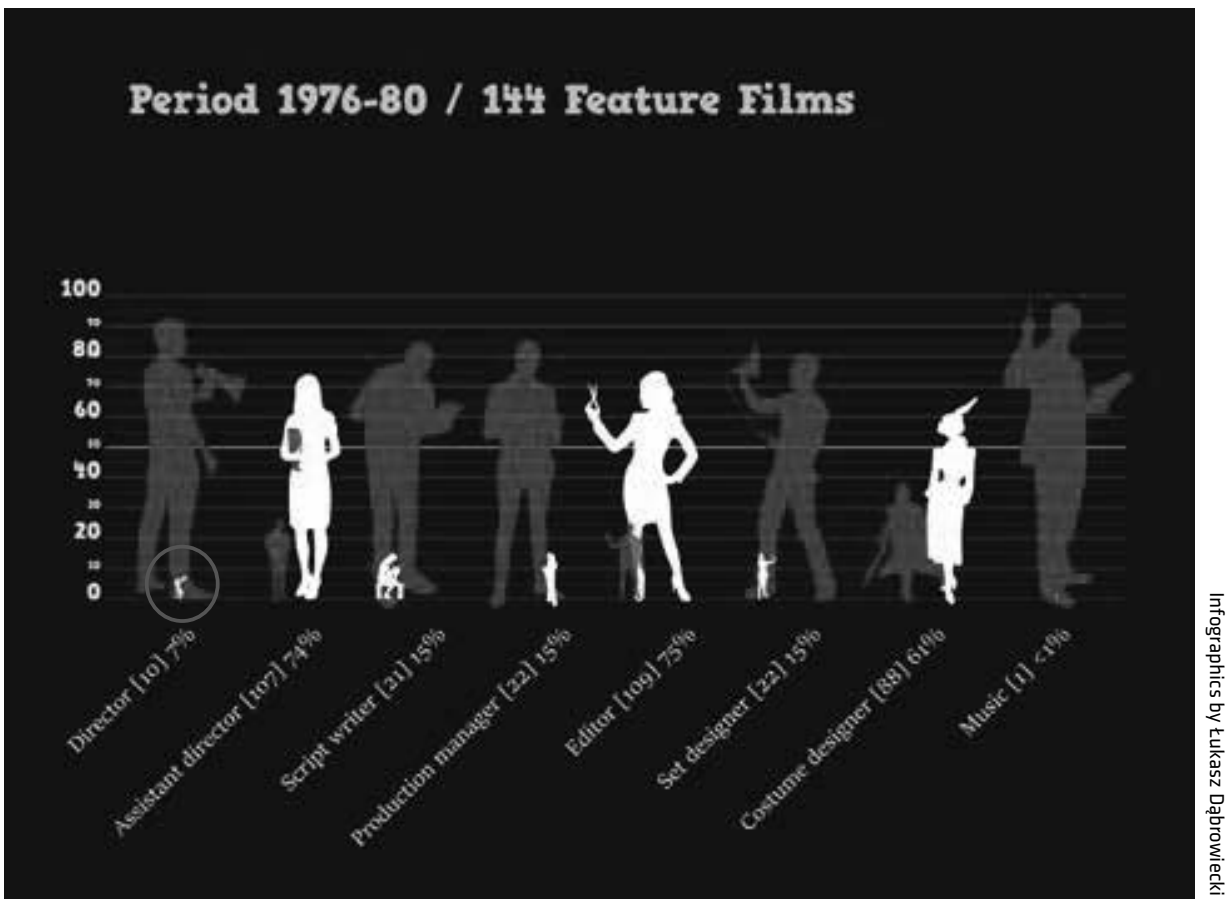

by waiting for a full-length feature debut soon left the Unit, but successfully debuted in another. The change also affected the representation of women on the screen, who more and more often became the heroines of full-length feature films as mature, professionally active people deciding to part with the traditional division of roles. Such protagonists were presented not only in women's cinema. It is enough to mention the films: Krzysztof Zanussi's Bilans kwartalny (Quarterly Balance Sheet, 1974), Barbara Sass's Bez mitości (Without Love, 1980), Agnieszka Holland's Kobieta samotna (Lonely Woman, 1981), Przestuchanie (Interrogation, 1982) by Ryszard Bugajski and others. What is more, the topic returned to the columns of the film press in a new shape, namely in the context of world cinema. The achievements of Polish women filmmakers and the image of the woman in Polish cinema were confronted with American, French, Italian, Soviet and German cinema. The monographic issue of the "Film na Świecie" magazine had been published in 1976 including Polish translations of the papers presented at the FEST'75 Film Festival in Belgrade and supplemented with Polish texts one of them being an article by an archivist of the National Film Archive in Warsaw, Ilona Szuster-Kacprzyk, entitled Polish Women's Cinema, which was before the feature debuts of Holland and Sass. According to the author, Polish women's cinema had already existed as a phenomenon in Polish film mainly through 
children's films, documentaries, educational and television films, and debutants in the medium-length film like Holland and Sass opened possibilities of its development (Szuster-Kacprzyk, 1976, pp. 93-98).

Let us note that despite the assumed criterion, i.e. the inclusion of women cinematographers in the study, the statistics do not record the case of a feature film with a woman as the DOP. The Polish school of cinematography remained the domain of outstanding men, despite the fact that from the beginning the Cinematography Department of the Film School in Łódź had also admitted female students (a total of 22 female students in 1948-1989). From the start, however, they would share the fate of being "one among the boys". As a result, they diverted to documentary and educational filmmaking or gave up cinematography for photography. Two cinematographers Nina Fleiszer-Berestowska (studies 1948-1953), who worked on educational films, and Elżbieta Zawistowska (studies 1952-57), who specialized on documentary films, having graduated in the period of women cinematographers inclusion in film industry are few outstanding exceptions. Among the graduates of the Cinematography Department two women photographers made a name for themselves in the history of Polish film: Zofia Nasierowska, as the author of portraits of film and theatre people, and Renata Pajchel, an outstanding stills photographer. The change came only in the 1990s and the digital breakthrough, which abolished the industry's most frequently repeated argument about the weight of film equipment exceeding the capabilities of a female operator. Almost as if the cinematography division consisted of only one person - a weightlifter, without numerous assistants, camera operators, grips etc. The same arguments were used and the same situation was present in the Hungarian film industry (Hock, 2012, p. 96).

\section{1-89}

In the eighties, the film industry experienced the effects of the imposition of Martial Law, the departure of viewers from cinemas in favour of the growing popularity of VHS and a decrease in interest in Polish film which the filmmakers tried to increase by incorporating eroticism into films and actresses appearing nude. Paradoxically, the participation of women in feature film costume design reached $81 \%$ (genre cinema was developing e.g. horror films, music films, retro films which required greater involvement in this respect), and in art direction it was the highest in the entire period studied reaching $18 \%$. What is more, in the field of editing, which was from the beginning women's domain, it reached 99\%! Several new names appeared in the author's film: Magdalena 


\section{Period 1981-89 / 277 Feature Films}

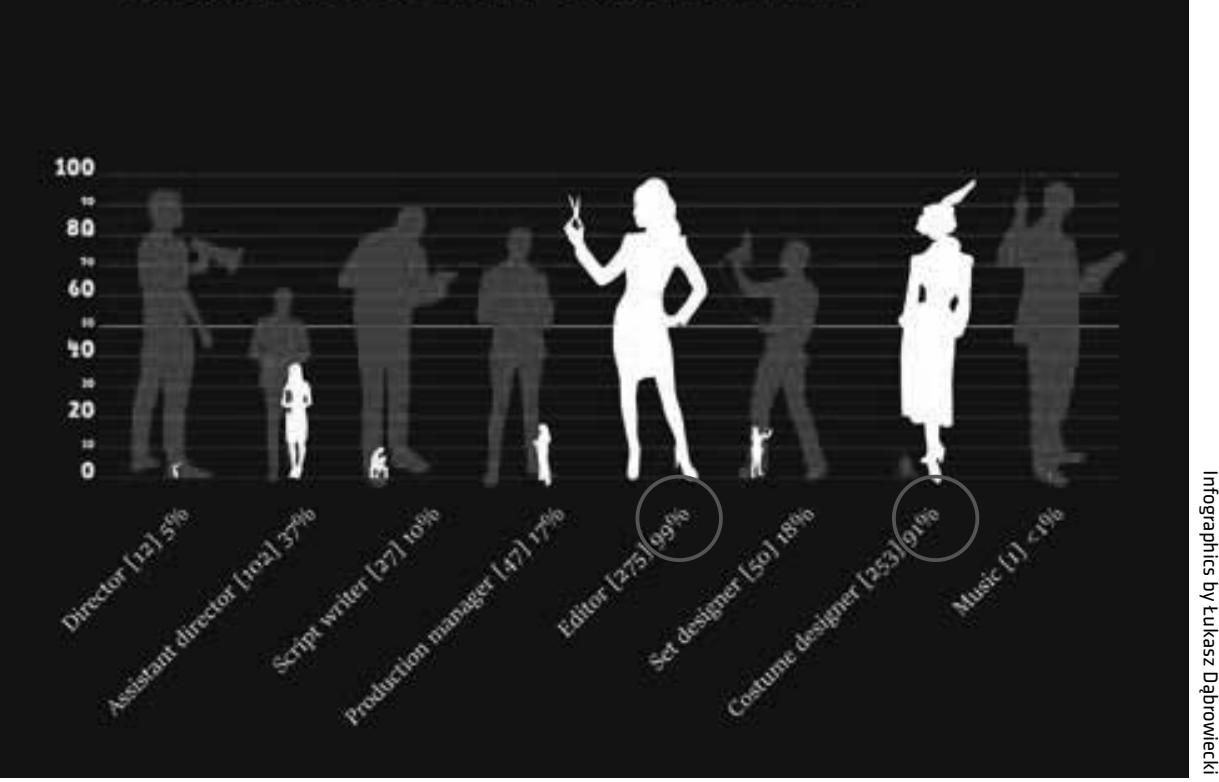

Łazarkiewicz, Grażyna Kędzielawska, Hanka Włodarczyk, Alina Skiba, but only for Eazarkiewicz it meant a career in the feature film and awards for women's cinema, such as the Audience Award at the International Women's Film Festival in Creteil for the debut Przez dotyk (Through Touch, 1986). The long-lived Wanda Jakubowska was saying goodbye to the audience with the last film in the camp series, Zaproszenie (Invitation, 1985) and the film about a poet, Kolory kochania (Colours of Love, 1988). Critics also announced the appearance on the screen of the first Polish feminist film - Bluszcz $(I v y, 1982)$ directed by Hanka Włodarczyk, based on the screenplay by Anda Rottenberg (Horoszczak, 1984, p. 14), which meant that contemporary Polish women - intellectuals were able to develop the next stage of emancipation, far from the Stalinist or their mothers' model. Nevertheless, the film had a bitter message and the director did not continue her film career. These were also the last years of Ewa Petelska's activity, who after 1989 and after the death of her husband did not go onto the film set ever again, although she lived until 2013, as she and her husband's position was inseparable from the political system. The discussion about women in the film industry, undertaken in the 1970s, had to give way to the leading issues: Solidarity and the crisis of the cinema. Three years after the martial law, in 1986, the circle of Polish feminists managed to organize the International Women's Films 
Days, in the "Hybrydy" club in Warsaw, that involved personally as guests Urlike Ottinger, Helke Sender, Livia Gyarmathy and others (Roszkowska, Ciechomska, 1986, pp. 23-26).

\section{Conclusions}

Summing up the quantitative results, it can be stated that female filmmakers over the years have marked their presence in most creative professions in the feature film with varying intensity. In the cinema of People's Poland they dominated the field of editing. If we decide that this is a creative but at the same time invisible work (taking place out of sight of the film crew, in the postproduction period, in close cooperation with the director), then it becomes clear that female editors were creatively responsible for most of the era's productions, not enjoying even the percentage of prestige that the directors had. The wellknown saying within the industry: "It can be saved in editing" encourages even greater appreciation of their work. Costume design turned out to be the second most dominated by women in the profession. This is not surprising, considering its relationship with fashion and tailoring, and editing with sewing and darning. Certainly, these results would coincide with the characterization of other professions in the set design division, with the exception of the highest in this hierarchy, art direction.

Female Lodz Film School directing graduates served as the director's support in almost half of the feature film crews. A strong entry into the direction of Wanda Jakubowska and the occupation of this position as the author of par excellance socialist cinema is an exception on the map of women's cinema in Central and Eastern Europe. Until the end of the 1970s, none could compare to her, and only when Agnieszka Holland in the short pre-emigration period in Poland grew to be an authority in Film Unit X and gained international recognition in exile Some, like Barbara Sass, even specialized in the position of the second director, up to the limits of frustration in her struggle for an individual debut. Film Unit X could also boast of a production manager - Barbara Pec-Ślesicka, despite the fact that the production management performed by women had never exceeded $10 \%$ in feature film production. Nevertheless, women held numerous medium and low-level positions in the administration of film units and editorial staff. The greatest number of independent women directors were employed by the Perspektywa Film Unit under the artistic direction of Janusz Morgenstern (Talarczyk, 2019, p. 42). Scriptwriting was not the domain of women either. In this field, in practice, feature films made were either based on the female directors' own scripts or were adaptations of women's prose, over the years no more than 
$11 \%$. Music and cinematography remained inaccessible areas to women artists until the 1990s.

In the Polish film industry, international trends went hand in hand with the feminization of editing and costume design as well as a lack of women's representation in cinematography and music, but in contrast to this, there was the unique participation of female directors directing feature films in comparison to world cinema, although it was still not big enough to be called a country of equal opportunities. Women's question appeared in the film industry of People's Poland long before it was introduced at the turn of the 1960s by feminist English-language film criticism and cinema in Western countries. The gender of the director and the image of the woman on the screen were the subject of debate first during the socialist realism period, and then briefly around 1968, to return in full force and in confrontation with the Western model in the mid-1970s. The silencing of these issues in the 1980s, in connection with Martial Law and subsequent fall of communism (cutting off from the postulates of the era and the dismantling of the state film industry institution) meant that feminism was rediscovered and shaped in Poland in a new way in the 1990s, including the reception of English-

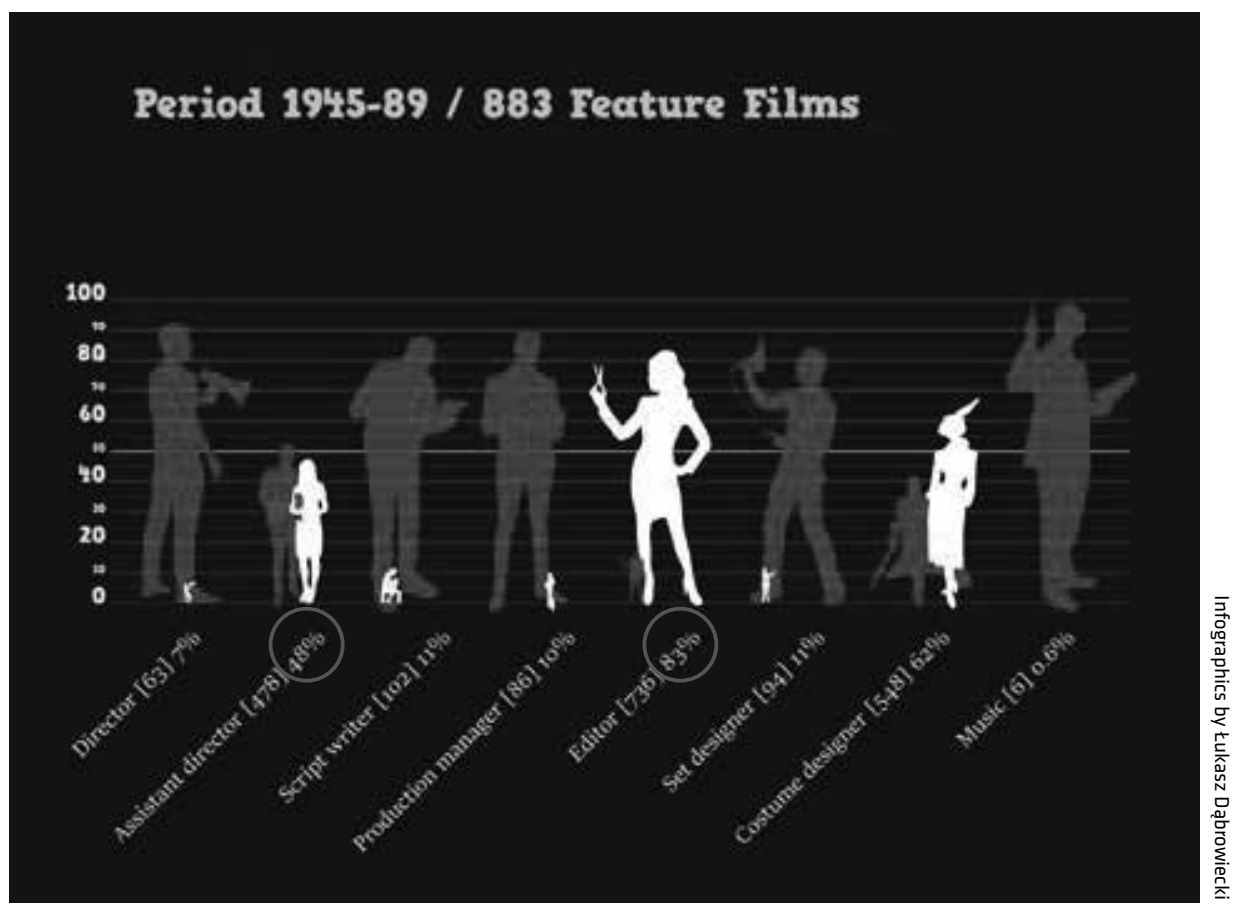


language feminist film criticism. It is time to restore the right proportions to two models of women's inclusion in Western and Eastern film industries, but first to get a complete picture of what happened to women filmmakers in the film industries of the former Eastern Bloc.

\section{References}

Caldwell, J.T. (2008). Production Culture: Industrial Reflexivity and Critical Practice in Film and Television. New York: Duke University Press.

Ciechomska, M.; Roszkowska, D. (1986). Kino źle obecne. „Kino”, no. 10.

Falkowska, J. (2003). Agnieszka Holland, Barbara Sass and Dorota Kedzierzawska in the World of Male Polish Filmmaking [in:] Women Filmmakers: Refocusing, ed. J. Levitin, J. Plessis and V. Raoul. Vancouver: University of British Columbia Press.

Hock, B. (2012). Coming into Age/ncy: Women in Filmmaking - The Hungarian Case. "Iluminace" vol. 24 , no. 4 .

Hock, B. (2010). Sites of Undoing Gender Hierarchies: Women andlin Hungarian Cinema (Industry). "Medijska istraživania / Media research", vol.16, no. 1.

Horoszczak, A. (1984). Rzecz o rozsypanych paciorkach (rec. filmu Bluszcz). „Kino”, no. 8.

Iordanova, D. (2003). Cinema of the Other Europe: The Industry and Artistry of East Central European Film. London: Wallflower.

Iskierko, A. (1969). Czy istnieja filmy męskie i damskie?. „Magazyn Filmowy”, no. 10.

Kael, P. (1963). Circles and Squares. „Film Quarterly”, vol. 16, no. 3.

Ostrowska, E., Mazierska, E. (2006). Women in Polish Cinema. New York: Berghahn.

Quart, B. (1988). Women Directors: the Emergence of New Cinema. New York: Praeger.

Szuster-Kacprzyk, I. (1976). Polskie kino kobiet. „Film na Świecie” no. 7.

Talarczyk, M. (2018). Montażyst(k)a, „Ekrany”, no. 5.

Talarczyk, M. (2019). Dobra karta Zespotu Perspektywa [in:] Zebra. 30 lat kręcenia, ed. A. Majer. Warszawa: Studio Zebra.

Talarczyk-Gubała, M. (2013a). Wszystko o Ewie. Filmy Barbary Sass a kino kobiet w drugiej potowie XX wieku. Szczecin: Wydawnictwo Naukowe Uniwersytetu Szczecińskiego.

Talarczyk-Gubała, M. (2013b). Biaty mazur. Kino kobiet w polskiej kinematografii. Poznań: Galeria Miejska Arsenał.

Talarczyk-Gubała, M. (2015). Wanda Jakubowska. Od nowa. Warszawa: Wydawnictwo Krytyki Politycznej. 


\begin{abstract}
The paper is dedicated to the Polish female filmmakers - contributors to feature film production from the period 1945-1989 in the Polish state film industry. The theoretical framework is based on women's studies and production studies. Author presents and comments on the numbers from the quantitative research, including credits of feature films production, divided into key positions: director, scriptwriter, cinematographer, music, editor, production manager, set designer and assistant director, costume designer. The results are presented in graphics and commented in 5 years blocs. The analysis leads to the conclusions describing the specificity of emancipation in socialist Poland in the area of creative work.
\end{abstract}

Key words: women's cinema; women's studies; production culture; Polish film, production studies 